\title{
Does Organizational Justice Moderate the Negative Influence of Job Insecurity on Organizational Commitment?
}

\author{
Anik Herminingsih
}

Program Studi Manajemen Universitas Mercu Buana, Jakarta Barat 11650, Indonesia

\begin{abstract}
A B S T R A C T
The increasing use of contract labor has triggered job insecurity resulting in a decline in organizational commitment. It is a challenge for the management of human resources to keep the committed employees by providing good treatments, for example, by giving a sense of justice of the organization. The study aims to analyze whether organizational justice moderates the negative influence of job insecurity on organizational employee commitment. The study involves 30 students of regular2; the data are obtained by filling in a self-rating questionnaire. The data are analyzed by using hierarchical regression model by using SPSS. The results show that job insecurity affects negatively and significantly on organizational employee commitment, while organizational justice affects positively and significantly on organizational employee commitment. Organizational justice has not been proven to moderate the influence of job insecurity on organizational employee commitment.
\end{abstract}

A R T I C L E I N F O

Article History:

Received : 27-12-2020

Revised : 20-07-2021

Accepted : 24-10-2021

Published : 31-10-2021

Keywords:

Moderation

Negative Influences

Organisasional Commitment Insecurity

JEL: M51, M52, M54

*Corresponding Author E-mail:

anik_herminingsih@mercubuana.ac.id

Copyright (C) 2021 Authors. This is an open access article distributed under the Creative Commons Attribution License (CC-BY-SA 4.0) which permits use, distribution and reproduction in any medium, provided the original work is properly cited \& ShareAlike terms followed.

\section{INTRODUCTION}

Companies in Indonesia have an increasing tendency to use outsourced employment (outsourcing). The use of contract labor has increased since the economic and monetary crisis hit Indonesia. The contract work system is usually applied to the type of supporting work that is not directly related to the core business of the company; the position levels are usually the lower staff levels. In practice the use of contract labor occurs almost in every type of work, not only in non-core or supporting jobs but also on permanent and core occupations, such as the work of doctors or nurses in hospitals, university 
lecturers, tellers in banking, and the practice of using contract labor for permanent employment in the company (Maryono, 2009). Based on observations, some employees have the contracts extended system over and over which indicates that their jobs are required by the company on a continuous basis rather than temporary. This is in accordance with the results of research Tjandraningsih et al (2010) that companies extend the contract labor 2.5 times but based on their research they found that the contracts are extended more than 3 times. In Riau Islands there are workers contracted up to 9 times, in West Java up to 15 times and in East Java up to 11 times.

Maryono (2009) states that the use of contract labor is an organizational strategy to cut costs. It is said that the contractual and outsourced work system on the one hand opens employment opportunities, and is considered better than unemployment. Tjandraningsih et al (2010) has findings that the practice of contractual and outsourced employment reflects the essence of labor outsourcing practices that require more serious handling because there are still multiple interpretations of the existing provisions.

Committed employees will do their jobs in best, and become organizational capital to gain competitive advantage. Mathew and Zajac (1990) state that if employees have a high commitment, then the company will get positive impacts such as increasing productivity, work quality and employee satisfaction as well as decreasing levels of delay, absence and turn over. In order to achieve maximum employee commitment, a company should fulfill employees' rights so that they can possess high loyalty and commitment. Employee commitment is a condition that characterizes relationships between employees and organizations having implications for individual decisions to stay or leave the organization. Decent salary in accordance with the burden / job responsibilities, job security, recognition of achievement, and opportunities to grow are some examples of the employees' rights. Furthermore, the fulfillment of these rights will lead to job satisfaction.

The results of the study by Ünsal-Akbiyık et al. (2012) show that non-permanent employees have higher job insecurity and affective commitment to a lower organization than permanent employees. The result of the research about work attitude of contract and outsourcing employees by Widodo (2010) shows that job insecurity of contract employee actually have a positive and significant effect on employee performance. Clark (2005) provides the temporary workers and permanent workers; temporary workers are differentiated as workers' own choice, and because of having no choice. Workers who choose to work temporarily have positive work results and do not differ significantly from permanent workers.

Irene (2008), reveals several factors that may affect the job insecurity are demographic characteristics (age, gender, length of service, marital status, and level of education), job characteristics, environmental conditions, ambiguity of roles, locus of control, and job value. It also discloses that vulnerable workers experiencing job insecurity include incompetent permanent employees, freelancers and contract workers, new employees who are on probation, and work from a secondary labor market, unskilled workers, seasonal workers and employees from contracting service providers. Job insecurity gives negative effects on both psychological and non-psychological aspects. Among the psychological aspects that arise include the decrease in job satisfaction, decreased creativity, feelings of gloom and guilt, anxiety and even anger. Manuaba \& Astiti (2014) reveals the significant relationship between job insecurity and organizational commitment and performance of contract employees. Job insecurity is negatively related to the performance of contract employees. Caballer and Peiró (2010) stated that job insecurity relates negatively to job satisfaction and organizational commitment and positively to intention to leave.

De Witte (2005) stated that it is important that 
companies give interventions aimed at improving control, for example by improving communication or participation in organizational decision making. This is necessary because it is likely to reduce job insecurity and the negative consequences of job insecurity on employees' behavior. Study by Rath (2011) showed that perceived procedural justice was a significant moderator in the relationship between the role stressors and general health. Results also show a direct relationship of justice perceptions with strains. The important of organizational justice as a moderator variable also found by Shahid et al. (2018), which their research indicated that organizational justice significantly moderate on the relationship of emotional exhaustion and job related outcomes (teachers learning, organizational commitment, and organizational loyalty).

Based on the previous statement, this research problems are : 1) Does job insecurity perceptions affect organizational employee commitment? 2) Does organizational justice affect organizational employee commitment? 3) Does organizational justice moderate the effect of job insecurity perceptions on organizational commitment?

When human resource policies have been established, related to contractual and outsourced employees, efforts should be taken to ensure that effectiveness can be achieved. The recommendations from the results of this study are expected to optimize the effectiveness of the companies implementing policies of contract and outsourcing system, especially addressing the negative impacts of job insecurity.

\section{LITERATURE REVIEW}

\section{Job Insecurity}

Job insecurity or the threat of unemployment is defined in various ways in the literature. Greenhalgh and Rosenblatt (1984) define job insecurity as the perceived powerlessness to maintain the desired continuity in a threatened job situation. Smithson and Lewis (2000) defines job insecurity as the psychological condition of an employee who has insecurity due to perceived impermanence. This condition arises because of the many types of work that are temporary or contract based work. The increasing number of jobs with temporary or non-permanent duration, causing more employees to experience job insecurity. De Witte (2005) made a conclusion that the job insecurity of employee makes consequences the feelings of helplessness to the desired job continuity.

\section{Dimensions of Job Insecurity}

Some opinions about job insecurity dimensions, as defined by Greenhalgh and Rosenblatt (1984) divide job insecurity into two dimensions, affective and cognitive. Affective means the employees' perception of job insecurity because of the fear of losing job. Cognitive means the employees' perception of job insecurity because of the fear that there is a risk of losing job.

\section{Measurement of Job Insecurity}

The measurement of job inscurity used in this study refers to the questionnaire developed by Elst el al. (2014) consisting of three questions to measure affective job insecurity and three questions for measuring cognitive job insecurity. Questions are prepared with multiple choice answers with Likert scale, scale 1 (strongly disagree) up to 5 (strongly agree).

\section{Organizational Commitment}

Meyer et al. (1997) define organizational commitment as a psychological condition that characterizes employee relationships with organizations, and furthermore, it has implications for their decision to continue or terminate their membership from the organization. In other words, they consider employees committed as people staying with organizations either in favorable or unfavorable conditions, they remain to work regularly and put themselves fully into achieving shared goals, values, and mission of the organization. Organizational commitment gains popularity in the field of organizational behavior and industrial and organizational psychology as it represents both affective (attitudes) and sustainable behavior in organizations (Allen and Meyer, 1990, Allen and Meyer 1993). 


\section{Organizational Commitment Dimension}

Allen and Meyer (1993) propose three models of organizational commitment and they are reflected in three main areas: 1) Affective commitment is the desire to work for a company because employees agree to the organization's goals and there is a desire to do it. 2) Continuance commitment is the desire to keep working on companies because they do not want to lose something related to their work. 3) Normative commitment is the desire to work for a company because of pressure from other parties.

Allen and Meyer (1993) argue that each component has a different basis, namely: 1) Affective components associated with emotional, identification and employee involvement within an organization. 2) The continuance component means a component based on the work's perception of the losses that will be faced if leaving the organization. 3) The normative component is the employees' feelings about the obligations that must be given to the organization. hhn

Employees with high affective components still join the organization because of the desire to remain to be members of the organization. Meanwhile, employees with high continuance components still join the organization because they need the organization. Employees with high normative components remain to be members of the organization because they have to do it. Every employee has a different base and behavior depending on his organizational commitment. Employees with an organizational commitment on an affective basis have different behaviors with employees based on continuance. Employees who wish to be members will have a desire to use the same effort as the organization's goal. Conversely, those who are forced to become members will avoid financial losses and other losses, so they may not do their best. Meanwhile, the normative component that develops as a result of the socialization experience, depends on to which the extent employees feel the obligation. The normative component creates a sense of duty to the employees to pay what they have received from the organization. This research uses the concept of organizational commitment as a multidimensional concept advocated by Allen and Meyer (1990).

\section{Organizational Justice}

Organizational justice refers to the perceived fairness of the exchanges taking place in an organization, be they social or economic and, involving the individual, in his or her relations with superiors, subordinates, peers; and the organization as a social system (Beugre, 1998). Organizational justice generally consists of three subdimensions: distributive justice, procedural justice, and interactional justice. Distributive justice is concerned with outcomes, such as salaries, rewards, and promotions (Colquitt, 2012).

\section{Dimensions of Organizational Justice}

The dimensions of organizational justice variables are 1) Distributive Justice; Distributive justice deals with the personal advantage of allocating resources within an organization. The period between the 1950s and 1970s, most organizational justice studies focused on distributive justice, based on the theory of social exchange (Colquitt, 2012). Homans (1961) suggests that individuals expect fair exchanges, and such perceptions depend on the objects of individual reference. In particular,

Adams (1965) uses equity theory to measure individuals' work motivation and satisfaction under three conditions under-reward, overreward, or fair rewards. Individuals who feel injustice based on comparisons with others are not on objective criteria. Empirical research has examined how people respond to the results of resource allocation decisions as a perceived function of justice. Individuals who are overpaid will feel guilty, while less-paid individuals will feel angry (Colquitt, 2012). Distributive justice comes from two types of comparison; comparisons of own outcomes and incomes (intrapersonal), and social comparison with others. As a consequence of perceived injustice, anger and aggression against the organization 
can be a cause for integrating distributive justice with procedural justice.

The rewards, especially the respect for one's status, are reflected in the treatment, especially of the powerful person, of the group members. Issues about wise and respectful treatment, respect for rights are parts of the rewards. The better the quality of treatment of groups or authorities to their members, the fairer the interaction is. The treatment that shows respect for others can be in the form of words, attitudes, or actions. Positive forms of appreciation include quick responses to questions or issues raised, appreciation of the work of others, helping, praising right actions or good results, and so on. In contrast, cursing, yelling, abandoning, humiliating, threatening, and deceiving are forms of behaviors that are contrary to respect (Donovan et al., In Faturochman, 2002).

\section{Previous Researches}

Various studies indicated the important of organizational commitment because its positive and significant impact on employee performance as Kristiwardhana (2011), Suharto et al. (2019) and Azlan et al. (2017). Nevertheless, the phenomenon of contract employees raises concerns about their commitment to the organization; several studies have shown that contract employees experience job insecurity as Adeugba and Oteyono (2012), Clark and Postel-Vinay (2005).

Anwar et al. (2011) stated that to retain their employees it is advisable to provide them with job security. The results of the study are supported by Dawson et al. (2014), Shakir and Zia (2014) stated that job stress is experienced by contractbased teachers. Research results by Nugraha (2010) showed that job insecurity variables negatively affect employee performance.

Research conducted by Guest and Clinton (2006) contradicts expectations, temporary contract workers report that they get better welfare, better public health, have more positive attitude toward work and better work behavior than their peers. A possible explanation lies in the decline value of permanent employment. Many workers continue to report high levels of workload, relatively high levels of irritation, anxiety and depression as well as a strong disruption of work to life at home. Temporary work may have disadvantages; but for many people, permanent workers turn out to have more negative things. Results of research by Wijaya (2010) state that job insecurity has a negative and significant impact on job satisfaction. The negative effects of job insecurity also found by Soelton et al. (2019) which their research found that there is a joint effect between job insecurity, work stress and work family conflict variables on employee burnout.

The inconsistency of the results of the study may be explained by the Selenko \& Paul (2011) focuses on the relationship between job insecurity and self-reported performance. They proposed that the relationship is U-shaped and mediated by forces in the workplace. Overall, the results show that the quadratic effect adds to the understanding of the relationship between job insecurity and self-reported work performance.

The existence of the role of the moderating variable of the influence of job insecurity on employee commitment is shown by the research of Noviarini (2013), that by including variabel locus of control in job insecurity relationship with organizational commitment and employee satisfaction hence group of employees with external locus of control in high job insecurity environment have commitment with the lowest job satisfaction compared to employees who have internal locus of control. The research by Winarsih and Riyanto (2020) showed that organizational justice had positive and significant impacts on positive behaviors, organizational commitment and significant organizational citizenship behaviors.

Study by Rath (2011) showed that perceived procedural justice was a significant moderator in the relationship between the role stressors and general health. Results also show a direct 
relationship of justice perceptions with strains. Results of Shahid et al. (2018) indicated that organizational justice significantly moderate on the relationship of emotional exhaustion and job related outcomes (teachers learning, organizational commitment, and organizational loyalty).

Based on previous theoretical and research review, this research uses job insecurity variable as independent variable (X1), and trust of organizational equity as moderating variable (X2). Organizational commitment as a dependent variable $(\mathrm{Y})$. The framework of research can be described as Figure 1.

\begin{tabular}{|c|c|c|}
\hline $\begin{array}{l}\text { Job Insecurity } \\
\text { - Affective } \\
\text { - Cognitive }\end{array}$ & $\uparrow>$ & $\begin{array}{l}\text { Organizational Commitment } \\
\text { - Affective } \\
\text { - Continuance }\end{array}$ \\
\hline $\begin{array}{l}\text { Orgar } \\
\text { - Distr } \\
\text { - Proc }\end{array}$ & $\begin{array}{l}\text { tional Ju } \\
\text { tive } \\
\text { ral }\end{array}$ & tice \\
\hline
\end{tabular}

Figure 1. Research Framework

\section{Research Hypotheses}

1. Job insecurity has a significant effect on organizational employee commitment.

2. Organizational justice has significant effect on organizational commitment.

3. Organizational justice moderates the influence of job insecurity on organizational commitment.

\section{RESEARCH METHODS}

The research design that the researcher uses is explanatory research, a research which aims to explain the causal relationship between variables through hypothesis testing. This design is commonly referred to as the causal design or hypothesis testing design, i.e. studies that include explaining certain relationships or determining the differences between groups or the independence of two or more factors in a situation (Sekaran, and Bougie, 2016).

The variables of this research consist of an independent variable (job insecurity), a dependent variable (organizational commitment), and a moderation variable (organizational justice).
Job insecurity is measured by employees' perceptions of their job insecurity, measured by two dimensions, affective dimension and cognitive dimension. Each dimension consists of 4 multiple choice questions with scores on the respondents' answers. Organizational justice is the perceptions of respondents about the treatment of justice received by respondents from the management, consisting of three dimensions of measurement namely the dimension of distributive justice, procedural justice and interactional justice. Organizational commitment is employees' perception of their attachment to the company in which they work today. Organizational commitment is measured by using 3 dimensions, namely affective commitment, continuance commitment and normative commitment. Each dimension consists of 5 questions.

The study uses primary data, obtained directly from the employees, who are the respondents of the study. The primary data in this study are obtained through questionnaires distributed to employees to be filled out by self-rating. The data collection technique in this study is survey method, by questionnaires.

The study population refers to the unit of analysis, i.e. individual employees. The research population is the student of the Magister Management program at Mercu Buana University in Jakarta Classes. The sampling technique is class sampling, i.e. five classes are selected randomly with the consideration that it will be obtained 125 samples.

The data collection uses questionnaires so they need to be tested the validity and reliability. Validity is measured by a correlation test between the questionnaire scores with the total score of constructs or variables. The score of each question item is considered valid or not, based on statistical criteria as follows: 1) If $r$-count> r-table and is positive, then the variable is valid. 2) If r-count $<r$-table, then the variable is invalid. 3) If $r$-count $>r$-table but it is marked negative, then the indicator is also considered invalid. 
The reliability of a question can be seen from the output of SPSS in the table with the title reliability statistics. A reliability test is a tool to measure a questionnaire that has indicators of variables or constructs. A questionnaire is considered reliable if one's response to a statement is consistent or stable over time. As Taherdoost, (2016) assessment of the reliability of each question item can be seen from the value of Cronbach's Alpha on each item. A question is said to be reliable when Cronbach's Alpha value is greater than 0.6 .

The research questions will be answered through a regression approach. The regression equation must meet the classical assumption, so it needs normality test, multicollinearity test, and heteroscedasticity test.

The multiple linear regression equation with the moderation variable is as follows:

$\mathrm{Y}=\mathrm{a}+\mathrm{b}_{1} \mathrm{X}_{1}+\mathrm{b}_{2} \mathrm{X}_{2}+\mathrm{b} 3 \mathrm{X}_{1} \mathrm{X}_{2}+\mathrm{e}$

Dimana :

$\mathrm{Y}=$ Organizational Commitment

$\mathrm{a} \quad=$ Constanta

b1 = Regression coefficient for job insecurity

b2 = Regression coefficient for organizational justice

b3 = Coefficient of moderation variables

$\mathrm{X} 1=$ Job insecurity

$\mathrm{X} 2$ = Justice of the organization

$\mathrm{X} 1 \mathrm{X} 2=$ Job Insecurity Interaction with Organizational Justice

$\mathrm{e} \quad=$ residual value

\section{Model Accuracy}

The accuracy of the model is tested through $\mathrm{F}$ (goodness of fit) test:

Ho: Accepted if F-count $\leq$ F-table

Ha: Accepted if F-count > F-table

If the value of F-count is greater than F-table, the model of regression equation has good goodness of fit.

Testing the influence of independent variables Hipotesis 1

Ho : b1 = 0: There is no effect of job insecurity on organizational commitment.
Ha $\quad: b 1 \neq 0$ : There is an effect of job insecurity on organizational commitment.

Criteria:

Ho accepted if $\mathrm{t}$-count $\leq \mathrm{t}$-table or $\alpha>0,05$

Ha accepted if $\mathrm{t}$-count $>\mathrm{t}$-table or $\alpha \leq 0,05$

Hipotesis 2

Ho $:$ b2 $=0$ : There is no effect of organizational justice on organizational commitment.

Ha $:$ b2 $\neq 0$ : There is an effect of organizational justice on organizational commitment.

Criteria:

Ho accepted if $t$-count $\leq \mathrm{t}$-table or $\alpha>0,05$

Ha accepted if t-count $>t$-table or $\alpha \leq 0,05$

Hipotesis 3

Ho :b3 = 0: Organizational justice does not moderate the influence of job insecurity on organizational commitment.

Ha $\quad: b 3 \neq 0$ : Organizational justice moderates the effect of job insecurity on organizational commitment.

Ho accepted if $\mathrm{t}$-count $\leq \mathrm{t}$-table or $\alpha>0,05$

Ha accepted if $t$-count $>t$-table or $\alpha \leq 0,05$

\section{RESULTS AND DISCUSSION}

The statistics of respondents' answers are used to know the condition of job insecurity, organizational justice and organizational commitment based on the respondents' perceptions. The statistics of respondents' answers presented in Table 2 shows that job insecurity is included in the low category with an average score of 2.385. This explains that most of the respondents are employees who have been settled in their work considering that the samples are regular 2 students of Mercu Buana University in the Magister Management program.

Organizational commitment is at a fairly good level, with an average score of 3.6466 . Organizational commitment still needs to be improved because the score 4 indicates the respondents agree and the score 5 indicates the respondents strongly agree with the statements that measure organizational commitment.

Organizational justice is also perceived by the 
Table 1. Respondents answer statistics

\begin{tabular}{lcccc}
\hline Variable/Dimension & Minimum & Maximum & Mean & Std. Deviation \\
\hline Job Insecurity & 1,38 & 3,88 & 2,3855 & 0,73213 \\
\hline JobInsecurity 1 & 1,25 & 4,75 & 2,4138 & 0,87698 \\
\hline Job Insecurity 2 & 1,25 & 4,00 & 2,3534 & 0,68634 \\
\hline Commitment & 1,73 & 4,73 & 3,6466 & 0,70087 \\
\hline Affective Commitment & 1,60 & 5,00 & 3,8000 & 0,84853 \\
\hline Continuance Commitment & 1,60 & 5,00 & 3,5517 & 0,81881 \\
\hline Normative Commitment & 2,00 & 4,60 & 3,5862 & 0,70494 \\
\hline Justice & 2,80 & 5,00 & 3,6876 & 0,44930 \\
\hline Distributive Justice & 2,00 & 5,00 & 3,5655 & 0,60016 \\
\hline Procedural Justice & 2,00 & 5,00 & 3,6069 & 0,68968 \\
\hline Instrument Justice & 2,40 & 5,00 & 3,8897 & 0,55443 \\
\hline
\end{tabular}

Source : Research data Processed (2020)

Table 2. Validity and Reliability Test Results

\begin{tabular}{lcccc}
\hline Variable/Dimension & Correlation Pearson & Validity & Cronbach' Alpha & Reliability \\
\hline Job Insecurity & & & & \\
\hline Affiliate JobInsecurity & 0,951 & valid & 0,845 & reliable \\
\hline Job Insecurity Cognitive & 0,919 & valid & & \\
\hline Commitment & & & & reliable \\
\hline Affective Commitment & 0,869 & valid & & \\
\hline Continuance Commitment & 0,959 & valid & 0,860 & \\
\hline Normative Commitment & 0,824 & valid & & reliable \\
\hline Justice & & & & \\
\hline Distributive Justice & 0,731 & valid & & \\
\hline Procedural Justice & 0,771 & valid & 0,65 & \\
\hline Instrument Justice & 0,679 & valid & & \\
\hline
\end{tabular}

Source: Research Data Processed (2020)

respondents quite well, seen from the average score of organizational justice of 3.6876 . Organizational justice is in a condition that still needs to be improved, given the score 4 indicates the respondents agree and the score 5 indicates the respondents strongly agree with the statements that measure organizational justice.

The testing the validity uses the criteria of correlation of each dimension with the total score of the overall dimensions on each variable. The result of the calculation using SPSS program is presented in Table 2. It shows that all dimensions have positive and significant correlation value and have greater value than the value of r-table. Based on these criteria, the overall dimensions used to measure the research variables are valid.
The result of reliability test of measuring the research instrument conducted with the criterion value of Cronbach's Alpha is bigger than 0,6. The result of the calculation of Cronbach's Alpha values are presented in Table 2. It shows that the value is greater than 0.6. This means that the overall research instruments of the study are valid so that they can be used to measure the research variables.

The classical assumption test is performed on regression analysis stage 2 , in which job insecurity and organizational justice variables are included as independent variables. The results of the classical assumption test are presented below. Test results with P-P Plots of standardized residual with dependent variable i.e. organizational commitment are presented in Figure 2. The graph 


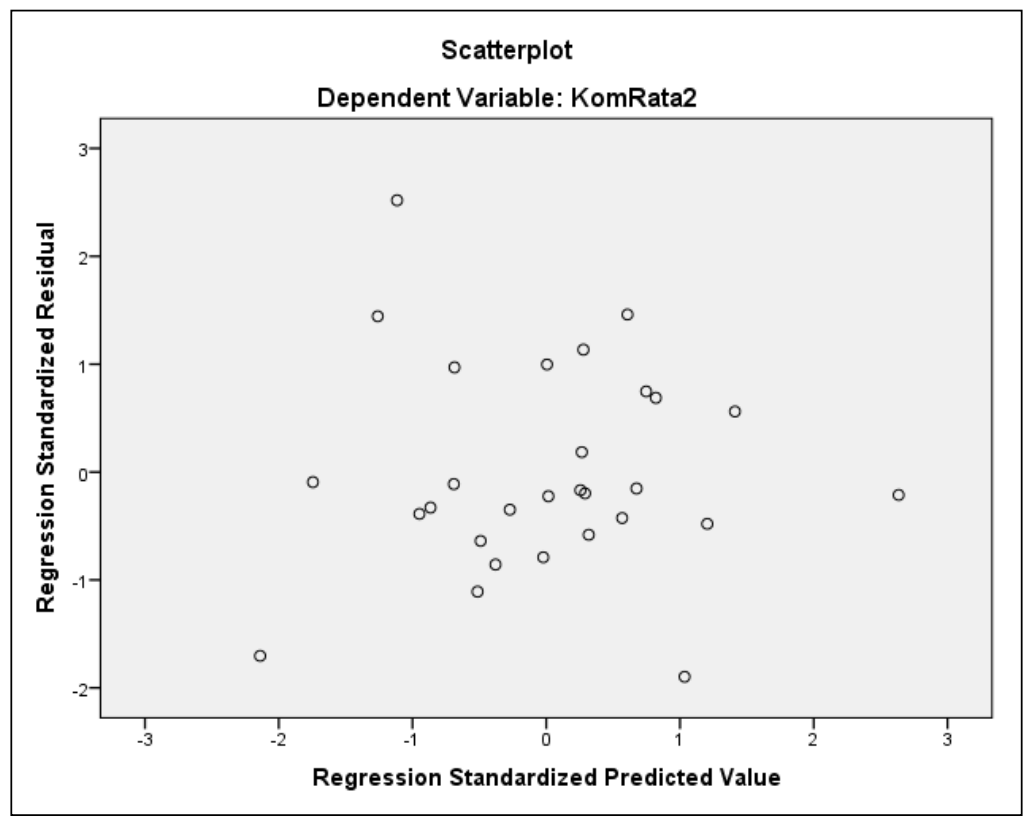

Figure 3. Heteroscedasticity Assumption Test Results

shows that the dots are a combination of standatdized residual with organizational commitment variable following diagonal line, so that normality assumption is fulfilled.

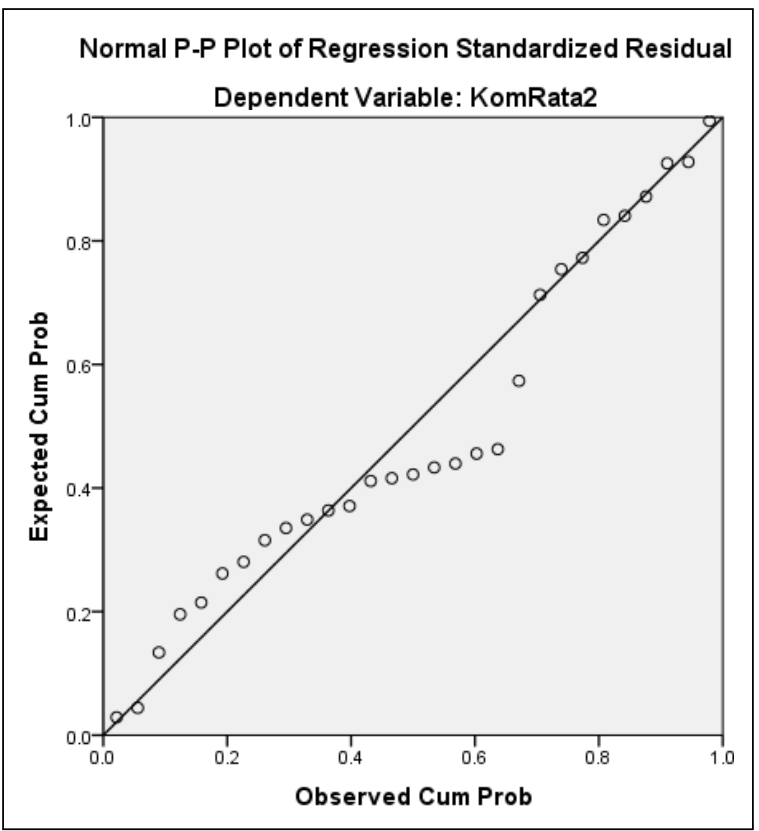

Figure 2. Normality Test Result with P-P Plot

The multicollinearity test results presented in Table 3 show that the overall tolerance value is greater than 0.10 and the overall VIF value is less than 10. Based on that, the research regression model meets the multicollinearity assumption.
Table 3. Multicollinearity Test Results

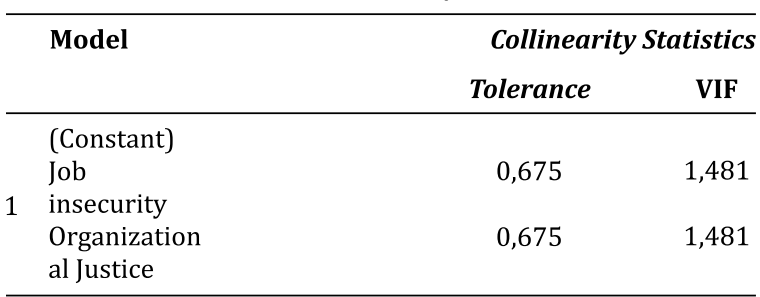

Testing of heteroscedasticity assumption is done by scatter plot method, in which the results are presented in Figure 2. The test results show that the result is spread and does not form a certain pattern. It means the model fulfills the assumption of heteroscedasticity.

\section{Hierarchical Regression Analysis}

To test the hypotheses in this study, the hierarchical regression analysis method is used. It consists of simple linear regression and moderation test. Before testing the hypotheses, the Goodness of Fit test is tested.

\section{Goodness of Fit Test}

This test is performed to see the fit of the research model by looking at the significant value of the overall model, i.e. by using the $F$ test and the significance level is less than 0.05 . If the value of significance is less than .5 then the model is feasible for use in the study. 
Table 4. Model Summary of Hierarchical Regression Model Summary ${ }^{\mathrm{d}}$

\begin{tabular}{|c|c|c|c|c|c|c|c|c|c|}
\hline \multirow[t]{2}{*}{ Model } & \multirow[t]{2}{*}{$\mathrm{R}$} & \multirow{2}{*}{$\begin{array}{c}\mathrm{R} \\
\text { Square }\end{array}$} & \multirow{2}{*}{$\begin{array}{l}\text { Adjusted } \\
\text { R Square }\end{array}$} & \multirow{2}{*}{$\begin{array}{l}\text { Std, Error of } \\
\text { the Estimate }\end{array}$} & \multicolumn{5}{|c|}{ Change Statistics } \\
\hline & & & & & R Square Change & F Change & df1 & df2 & Sig, F Change \\
\hline 1 & $0,458^{a}$ & 0,210 & 0,181 & 0,63444 & 0,210 & 7,171 & 1 & 27 & 0,012 \\
\hline 2 & $0,650^{\mathrm{b}}$ & 0,423 & 0,378 & 0,55254 & 0,213 & 9,597 & 1 & 26 & 0,005 \\
\hline 3 & $0,660^{c}$ & 0,436 & 0,369 & 0,55693 & 0,013 & 0,591 & 1 & 25 & 0,449 \\
\hline
\end{tabular}

a. Predictors: (Constant), Job Insecurity

b. Predictors: (Constant), Job insecurity, Organizational Justice

c. Predictors: (Constant), Job insecurity, Interaction Organizational Justice

d. Dependent Variable: Organizational Commitment

Table 5. The Value of t-count Multiple Hierarchical Linear Regression Model Coefficients ${ }^{a}$

\begin{tabular}{|c|c|c|c|c|c|c|}
\hline \multirow{2}{*}{\multicolumn{2}{|c|}{ Model }} & \multicolumn{2}{|c|}{ Unstandardized Coefficients } & \multirow[t]{2}{*}{ Standardized Coefficients Beta } & \multirow[t]{2}{*}{$\mathbf{t}$} & \multirow[t]{2}{*}{ Sig. } \\
\hline & & B & Std. Error & & & \\
\hline \multirow{2}{*}{1} & (Constant) & 4,693 & 0,408 & & 11,501 & 0,000 \\
\hline & Job insecurity & $-0,439$ & 0,164 & $-0,458$ & $-2,678$ & 0,012 \\
\hline \multirow{3}{*}{2} & (Constant) & 0,730 & 1,328 & & 0,550 & 0,587 \\
\hline & Job insecurity & $-0,132$ & 0,174 & $-0,138$ & $-0,760$ & 0,454 \\
\hline & Organizational justice & 0,876 & 0,283 & 0,562 & 3,098 & 0,005 \\
\hline \multirow{4}{*}{3} & (Constant) & 2,975 & 3,211 & & 0,926 & 0,363 \\
\hline & Job insecurity & $-1,051$ & 1,208 & $-1,098$ & $-0,870$ & 0,392 \\
\hline & Organizational justice & 0,254 & 0,858 & 0,163 & 0,296 & 0,770 \\
\hline & Interaction & 0,260 & 0,339 & 0,811 & 0,769 & 0,449 \\
\hline
\end{tabular}

a. Dependent Variable: KomRata2

In Table 4, there are three types of models, namely model 1 , model 2 , and model 3 , each of which has different predictors coming in the regression. When Model 1 (which contains job insecurity only), the predictor contribution of $21.0 \%$ (see R-square). The value of $\mathrm{F}$ is 7,171 ( $\mathrm{p}=$ 0.012 ; $\mathrm{p}<0.05$ ). This means that job insecurity can predict organizational commitment negatively and significantly.

Model 2 has incorporated organizational fairness variables in the regression model. It turns out that organizational justice is also able to predict organizational commitment well, as proven from its contribution increasing from $21.0 \%$ to $42.3 \%$. This contribution is significant as seen from the significant change of $\mathrm{F}$ or F-Change $=9,597(\mathrm{p}=$ 0.005; $\mathrm{p}<0.01$ ).

Model 3 is a model by including the interaction between job insecurity with organizational justice. It turns out that the addition of interaction variables only slightly increases the R-square value from $42.3 \%$ to $43.6 \%$ in which the change also occurs in the value F-count from 0.005 to 0,449 . Based on it, model 3 is not better than model 2.

\section{Hypothesis testing}

To test the effect of job insecurity on organizational commitment (hypothesis 1), the simple linear regression is used. While to examine the effect of organizational justice as a moderating variable on the influence of job insecurity toward organizational commitment, the multiple linear regression analysis model with t-test criteria of job insecurity variable interaction with organizational justice is used. The test results are presented in Table 5.

As presented in Table 5, in model 1 it can be concluded that job insecurity has a negative and significant effect on organizational commitment. The more insecure employees feel at work, the lower the employee commitment to the organization is. Model 2 is done by incorporating organizational justice into the model. The test result with model 2 shows the influence of job 
insecurity on organizational commitment is not significant while the influence of organizational justice toward organizational commitment is positive and significant. It means that the more fairly employees are treated, the higher the organizational employee commitment is.

Testing with model 3 incorporates an interaction variable. Interaction variable is a variable formed by multiplying job insecurity variable with organizational justice variable. The result of the regression by entering the interaction variable into the regression model gives the t-count value for the three variables is not significant. Based on the above, it can be concluded that organizational justice is not proven to be a variable that moderates the influence of job insecurity on organizational commitment.

The results show that organizational justice is a more important factor affecting organizational employee commitment, as indicated by positive and greater regression coefficients than the negative effects of job insecurity. This is in accordance with the results of the previous research by Mahrani et al. (2015), Aküzüm (2014), Turgut et al. (2012), Malik and Naeem (2011), Jawad et al. (2012), Hassan (2002), Leow and Khong (2009), Akanbi and Ofoegbu (2013), Raza et al. (2013), and Gayipov and
Bedük (2014) which state that organizational justice is an important factor in shaping organizational employee commitment. But this research did not support Rath (2011) and Shahid et al. (2018), which organizational justice moderate the relatonship between negative perception on employee outcome behaviors.

\section{CONCLUSION AND RECOMMENDATION}

The conclusion of this study is job insecurity has a negative and significant effect on organizational employee commitment, 2) organizational justice has a positive and significant impact on organizational employee commitment and 3) organizational justice is not proven to moderate the influence of job insecurity perception on organizational employee commitment.

Based on the results of the research, the organizational justice is not proven to moderate the influence of job insecurity to organizational employee commitment. However, the results of the study show that organizational justice has a positive and significant effect on organizational employee commitment. The recommendation that can be given to management to increase organizational commitment is to provide a sense of justice to employees. It is expected to reduce the negative effects of job insecurity felt by employees on their organizational commitment.

\section{RE FERE N C ES}

Adenugba, A.A. and Oteyowo, 0.,2012. Job Insecurity in Selected Banks in Ibadan Southwest Nigeria. Mediterranean Journal of Social Sciences Vol. 3 (2), pp : 47-60.

Akanbi, P.A.and Ofoegbu, O.E., 2013. Impact of Perceived Organizational Justice on Organizational Commitment of a Food and Beverage Firm in Nigeria. International Journal of Humanities and Social Science Vol. 3 No. 14, pp: 207-218.

Aküzüm, C., 2014,The Effect of Organizational Justice and Organizational Cynicism on the Organizational Commitment: An Application in Primary Education Institutions. Mevlana International Journal of Education (MIJE), Vol. 4 No.3, pp: 48-68.

Anwar, M.S., Aslam, M., and Tariq, M.R., 2011. Temporary Job and its Impact on Employee Performance. Global Journal of Management and Business Research Volume 11 Issue 8, pp: 23-28.

Azlan, N.N.A., Abdullah, N., Fadhilah, A., and Zahari, A.S.M. 2017. The Organizational Commitment towards Employee's Performance: A Case Study at Elektro Serve (M) Sdn Bhd. J. Appl. Environ. Biol. Sci., 7(12)134-145, 2017.

Beugre, C.D. 1998. Managing Fairness in Organizations. Greenwood Pub. Gr, Westport, CT, USA. 
Caballer, B.S.A. and Peiró, J.M. 2010. The consequences of job insecurity for employees: The moderator role of job dependence. International Labour Review, Vol. 149, No. 1, pp: 59-71.

Clark, L.J., 2005. Moderators of the Effects of Percieved Job Insecurity : A Comparison of Temporary and Permanent Employees. Thesis submitted to the Doctor of Philosophy, Queensland University of Technology. Brisbane.

Colquit, J.A. 2012 in Kozlowski (Ed), The Oxford Hanbook of Organizational Psychology. Oxford University Press. New York.

De Witte, H. 2005. Job Insecurity: Review of The International Literature On Definitions, Prevalence, Antecedents And Consequences. Sa Journal of Industrial Psychology, 2005, 31 (4), 1-6

Elst, T.V., De Witte, H., \& De Cuyper, N. (2014) The Job Insecurity Scale: A psychometric evaluation across five European countries, European Journal of Work and Organizational Psychology, Vol.,23, No.3, pp:364-380,

Faturochman. 2002. Keterkaitan antara Anteseden, Penilaian Keadilan Prosedural, Penilaian Keadilan Distributif, dan Dampaknya. Disertasi Universitas Gadjah Mada. Yogyakarta.

Gayipov, Y. and Bedük, A.,.2014. The Relationship of Organizational Justice with Organizational Commitment: An Implementation in an Education Institution in City of Konya. International Journal of Business and Social Science, Vol. 5, No. 11, pp: 75-84.

Greenhalgh, L. \& Rosenblatt, Z. (1984). Job insecurity: Toward conceptual clarity. Academy of management review, 9 (3), 438-448.

Guest, D, \& Clinton, M, 2006. Temporary employment contracts, workers' well-being and behaviour: evidence from the UK. Department of Management Working Paper No. 38, King's College, London.

Hassan, A., 2002. Organizational Justice as a Determinant of Organizational Commitment and Intention to Leave. Asian Academy of Management Journal, Vol. 7, No. 2, pp: 55-66.

Irene, J. 2008. Hubungan antara Occupational Self-Efficcacy dan Job Insecurity pada Tenaga KerjaOutsourcing.www.digilib.ui.ac

Jawad, M., Raja, S., Abraiz, A. and Tabassum, T.M., 2012. Role of Organizational justice in organizational commitment with moderating effect of employee work attitudes. OSR Journal of Business and Management (IOSR-JBM),Vol. 5, No.4, pp:39 - 45

Kristiwardhana, A.,2011. Analisis Pengaruh Motivasi Kerja dan Komitmen Organisasional terhadap Kinerja Karyawan (Studi pada BPR Estetika Artha Guna Semarang). Fakultas Ekonomi Universitas Diponegoro. Semarang.

Leow, K.L., and Khong, K.W., 2009. Organizational Commitment:The Study of Organizational Justice and Leader Member Exchange (LMX) Among Auditors in Malaysia. International Journal of Business and Information, Vol. 4, No. 2, pp: 161-198.

Manuaba, I.A.A.M. \& Astiti, D.P., 2014. Hubungan Ketidakamanan Kerja dan Komitmen Organisasi terhadap Kinerja Karyawan Kontrak Pada Pt. Bank Cimb Niaga Tbk, Wilayah Bali. JurnalPsikologiUdayana 2014, Vol.1, No.3, 25- 40.

Maryono. 2009. Tenaga Kontrak : Manfaar dan Permasalahannya. Jurnal Bisnis dan Ekonomi (JBE), Vol.16, No.1, pp: 26-31.

Mahrani, S.W., Kamaluddin, M., Takdir, D.S, and Ansir.2015. Organizational Justice and Organizational Commitment. International Journal of Science and Research (IJSR), Vol.4, No.3, pp:627-632.

Malik, M.E. and Naeem, B., 2011, Impact of Perceived Organizational Justice on Organizational Commitment of Faculty : Empirical Evidence from Pakistan. Interdisciplinary Journal of Research in Business ,Vol. 1, No.9, pp:92-98.

Mathieu, J.E., \& Zajac, D.M. 1990. A review and meta- analysis of the antecedents, correlates and consequences of organizational commitment. Psychological Bulletin, 108, 171-194.

Meyer, J.P., Allen, N.J., and Meyer, D.R. 1997. Commitment in the Workplace : Theory, Research, and Application. SAGE Publishing. California. 
Noviarini, N.M.,. 2013. Peran Locus of Control dalam Hubungan Job Insecurity dengan Komitmen Organisasi dan Kepuasan Kerja. Studi Kasus : Karyawan PLN Denpasar. Pada Program Magister, Program Studi Manajemen Program Pascasarjana Universitas Udayana.

Nugraha, A.,2010. Analisis Pengaruh Ketidakamanan Kerja dan Kepuasan Kompensasi terhadap Kinerja Karyawan (Studi pada karyawan kontrak PT Bank Rakyat Indonesia cabang Semarang Patimura dan Unit Kerjanya). Program Sarjana Fakultas Ekonomi Universitas Diponegoro. Semarang.

Rath, J., 2011. Moderating Role Of Justice Perception In The Relationships Between Stressors And Strains. A Thesis Presented To The Faculty Of The Department Of Psychology San José State University. San Jose.

Raza, K., Rana,N.R., Qadir, M., and Rana, A.M.,. 2013. Relationship Between Distributive, Procedural Justice and Organizational Commitment: An Empirical Analysis on Public Sector of Pakistan. Middle-East Journal of Scientific Research, Vol.16, No.6, pp: 878-883.

Shahid, A., Nisar, Q.A., Azeem, M., Hameed, W.U., and Hussain, S. 2018. Moderating Role of Organizational Justice between Emotional Exhaustion and Job-Related Outcomes. Pakistan Journal of Humanities and Social Sciences, Vol.6, No. 2, pp:205 - 220.

Shakir, M. and Zia, A.. 2014. Temporary Job and Permanent Stress. Journal of Education and Practice, Vol.5, No.14, pp: 144-150.

Selenko, E., Batinic, B., \& Paul, K. I. (2011). Does latent deprivation lead to psychological distress? Investigating Jahoda's model in a four-wave study. Journal of Occupational and Organizational Psychology, 84, 723-740.

Sekaran, U., and Bougie, R., 2016. Research Methods for Business A Skill-Building Approach Seventh Edition. John Wiley \& Sons Ltd, West Sussex, United Kingdom.

Smithson, J and Lewis, S. (2000),"Is job insecurity changing the psychological contract?", Personnel Review, Vol. 29, No.6, pp. $680-702$

Suharto, S., and Hendri, N. 2019. The Impact of Organizational Commitment on Job Performance. International Journal of Economics and Business Administration Volume VII, Issue 2, 2019 pp. 189-206.

Taherdoost, H., 2016. Validity and Reliability of the Research Instrument; How to Test the Validation of a Questionnaire/Survey in a Research . International Journal of Academic Research in Management (IJARM) Vol. 5, No. 3, 2016, Page: 28-36, ISSN: 2296-1747.

Tjandraningsih, I., Herawati, R., dan Suhadmadi. 2010. Diskriminatif dan Eksploitatif : Praltek Kerja Kontrak dan Outsourching Buruh di Sektor Industri Metal di Indonesia. Akatiga. Pusat Analisis Sosial. Bandung.

Turgut, H., Tokmak, I.and Gucel, C., 2012. The Effect of Employees' Organizational Justice Perceptions on Their Organizational Commitment : A University Sample. International Journal of Business and Management Studies. Vol 4, No 2, pp: 21-30.

Unsal-Akbyik, B.S.,Otluoglu,K., O.C., and De Witte, H. .2012. Job Insecurity and Affective Commitment in Seasonal Versus Permanent Workers International Journal of Humanities and Social Science, Vol. 2, No. 24, pp:14-20.

Widodo, R.2010. Analisis Pengaruh Kemanan Kerja dan Komitmen Oranisasional terhadap Turnover Intention serta Dampaknya pada Kinerja Karyawan Outsourcing. (Studi Pada PT. PLN Persero APJ Yogyakarta).Tesis. Program Magister Manajemen Universitas Diponegoro. Semarang.

Wijaya, E. F.. 2010. Pengaruh Job Insecurity, Komitmen Karyawan dan Kepuasan Kerja terhadap Intention to Quit (Studi pada PT. Bank Jatim Cabang Malang). Program Magister Manajemen Pascasarjana Fakultas Ekonomi Universitas Brawijaya. Malang.

Wulandari, R.,2008. Pengaruh Komitmen Organisasional terhadap Kinerja Karyawan PT. BPR Setia Karib Abadi Semarang. Fakultas Ekonomi Universitas Soegijapradja. Semarang. 